\title{
Zinc phosphate-based nanoparticles as a novel antibacterial agent: in vivo study on rats after dietary exposure
}

Pavel Horky' ${ }^{1}$ Sylvie Skalickova', Lenka Urbankova', Daria Baholet ${ }^{1}$, Silvia Kociova², Zuzana Bytesnikova², Eliska Kabourkova², Zuzana Lackova ${ }^{2,3}$, Natalia Cernei ${ }^{2,3}$, Milica Gagic $^{2}$, Vedran Milosavljevic ${ }^{2,3}$, Vendula Smolikova ${ }^{2,3}$, Eva Vaclavkova ${ }^{4}$, Pavel Nevrkla ${ }^{5}$, Pavel Knot ${ }^{1}$, Olga Krystofova ${ }^{2,3}$, David Hynek ${ }^{2,3}$, Pavel Kopel ${ }^{2,3}$, Jiri Skladanka ${ }^{1}$, Vojtech Adam ${ }^{2,3}$ and Kristyna Smerkova ${ }^{2,3^{*}}$ (D)

\begin{abstract}
Background: Development of new nanomaterials that inhibit or kill bacteria is an important and timely research topic. For example, financial losses due to infectious diseases, such as diarrhea, are a major concern in livestock productions around the world. Antimicrobial nanoparticles (NPs) represent a promising alternative to antibiotics and may lower antibiotic use and consequently spread of antibiotic resistance traits among bacteria, including pathogens.

Results: Four formulations of zinc nanoparticles (ZnA, ZnB, ZnC, and ZnD) based on phosphates with spherical (ZnA, ZnB) or irregular (ZnC, ZnD) morphology were prepared. The highest in vitro inhibitory effect of our NPs was observed against Staphylococcus aureus (inhibitory concentration values, $I_{50}$, ranged from 0.5 to $1.6 \mathrm{mmol} / \mathrm{L}$ ), followed by Escherichia coli $\left(I C_{50} 0.8-1.5 \mathrm{mmol} / \mathrm{L}\right)$. In contrast, methicillin resistant $S$. aureus $\left(\mathrm{IC}_{50} 1.2-4.7 \mathrm{mmol} / \mathrm{L}\right)$ was least affected and this was similar to inhibitory patterns of commercial ZnO-based NPs and ZnO. After the successful in vitro testing, the in vivo study with rats based on dietary supplementation with zinc NPs was conducted. Four groups of rats were treated by 2,000 mg $\mathrm{Zn} / \mathrm{kg}$ diet of $\mathrm{ZnA}, \mathrm{ZnB}, \mathrm{ZnC}$, and ZnD, for comparison two groups were supplemented by 2,000 mg Zn/kg diet of ZnO-N and $\mathrm{ZnO}$, and one group (control) was fed only by basal diet. The significantly higher $(P<0.05) \mathrm{Zn}$ level in liver and kidney of all treated groups was found, nevertheless Zn NPs did not greatly influence antioxidant status of rats. However, the total aerobic and coliform bacterial population in rat feces significantly decreased $(P<0.05)$ in all zinc groups after 30 $\mathrm{d}$ of the treatment. Furthermore, when compared to the $\mathrm{ZnO}$ group, $\mathrm{ZnA}$ and $\mathrm{ZnC}$ nanoparticles reduced coliforms significantly more $(P<0.05)$.
\end{abstract}

Conclusions: Our results demonstrate that phosphate-based zinc nanoparticles have the potential to act as antibiotic agents.

Keywords: Aerobic bacteria, Antibiotics, Coliforms, Nanomaterials, Oxidative stress

\section{Background}

Zinc-based nanomaterials have been applied in several fields including agriculture, chemistry, textile and food industry, electronics, and medicine [1-7]. Due to their antibacterial activity, the $\mathrm{Zn}$ nanoparticles (NPs), particularly $\mathrm{ZnO}$-based, have been designed and tested for

\footnotetext{
* Correspondence: kristyna.smerkova@mendelu.cz

${ }^{2}$ Department of Chemistry and Biochemistry, Mendel University in Brno, Zemedelska 1, CZ-613 00 Brno, Czech Republic

${ }^{3}$ Central European Institute of Technology, Brno University of Technology, Purkynova 123, CZ-612 00 Brno, Czech Republic

Full list of author information is available at the end of the article
}

utilization in veterinary and human medicine. Their bactericidal ability has been demonstrated against diverse bacterial species, including pathogens Listeria monocytogenes, Escherichia coli, Staphylococcus aureus, Pseudomonas aeruginosa, Campylobacter jejuni, Salmonella enterica [8-11] and antibiotic-resistant strains including methicillin resistant $S$. aureus (MRSA) and extended spectrum beta-lactamases producing E. coli and Klebsiella pneumoniae [12, 13]. Considering their substantial bactericidal potential, $\mathrm{Zn}$ nanoparticles represent

(c) The Author(s). 2019 Open Access This article is distributed under the terms of the Creative Commons Attribution 4.0 International License (http://creativecommons.org/licenses/by/4.0/), which permits unrestricted use, distribution, and reproduction in any medium, provided you give appropriate credit to the original author(s) and the source, provide a link to the Creative Commons license, and indicate if changes were made. The Creative Commons Public Domain Dedication waiver (http://creativecommons.org/publicdomain/zero/1.0/) applies to the data made available in this article, unless otherwise stated. 
promising alternatives to antibiotics or an enhancement of antibiotics against drug resistant bacteria [14].

The exact mode of action of Zn NPs is not well understood; however, one of the most plausible mechanisms comprises generation of reactive oxygen species (ROS). The highly reactive hydroxyl radicals are able to enter bacterial cells and damage them, while superoxide anions or hydrogen peroxide are considered less toxic [15, 16]. Another mechanism may involve disruption of the bacterial cell wall after the contact with nanoparticles $[17,18]$. Furthermore, metal NPs are also able to induce different biological responses in eukaryotes $[19,20]$. Due to ROS production, the $\mathrm{ZnO}$ NPs cause oxidative stress which leads to inflammation and even death of mammalian cell lines [21].

In the present study, four phosphate-based NPs formulations were synthesized and characterized. After confirmation of their antibacterial activity in vitro, the study on rats was conducted. The in vivo test aimed to determine whether the selected phosphate-based NPs have comparable effect to $\mathrm{ZnO}$ and $\mathrm{ZnO}$ NPs on the gut microbiome and on overall health of rats as a model organism.

\section{Methods}

\section{Chemicals}

All chemicals were purchased from Sigma Aldrich (St. Louis, MO, USA) and Penta (Prague, Czech Republic) of p.a. purity, unless noted otherwise. The $\mathrm{pH}$ value was measured using inoLab ${ }^{\circ}$ Level 3 (WissenschaftlichTechnische Werkstatten GmbH; Weilheim, Germany). Deionised water underwent demineralization by reverse osmosis using the instruments Aqua Osmotic 02 (Aqua Osmotic, Tisnov, Czech Republic) and it was subsequently purified using Millipore RG (Millipore Corp., Waltham, MA, USA) - $18 \mathrm{M}^{\prime} \Omega$ MilliQ water.

$\mathrm{ZnO}$ and $\mathrm{ZnO}$-based NPs (ZnO-N) were supplied by Sigma-Aldrich. According to manufacturer, the average particle size was $\leq 100 \mathrm{~nm}$ (see Additional file 1: Figure S1).

\section{Zinc NPs synthesis}

$\mathrm{ZnA}$

$\mathrm{Zn}\left(\mathrm{NO}_{3}\right)_{2} \cdot 6 \mathrm{H}_{2} \mathrm{O}(4.46 \mathrm{~g})$ was dissolved in water $(50 \mathrm{~mL})$ and solution was heated to $60{ }^{\circ} \mathrm{C}$. $\left(\mathrm{NH}_{4}\right)_{2} \mathrm{HPO}_{4}(1.32 \mathrm{~g}$ in $20 \mathrm{~mL}$ of water) was added while stirring and white precipitate was immediately formed. The suspension was stirred for $2 \mathrm{~h}$, cooled and water was added to reach 100 $\mathrm{mL}$.

\section{$\mathrm{ZnB}$}

Zinc phosphate was prepared as described above, only sodium salt $\mathrm{Na}_{2} \mathrm{HPO}_{4} \cdot 7 \mathrm{H}_{2} \mathrm{O}(2.68 \mathrm{~g})$ was used instead of ammonium salt.

\section{$\mathrm{ZnC}$}

$\mathrm{Zn}\left(\mathrm{NO}_{3}\right)_{2} \cdot 6 \mathrm{H}_{2} \mathrm{O}(3 \mathrm{~g})$ was dissolved in water $(50 \mathrm{~mL})$ and solution was heated to $60^{\circ} \mathrm{C} . \mathrm{Na}_{4} \mathrm{P}_{2} \mathrm{O}_{7}(1.33 \mathrm{~g}$ in 20 $\mathrm{mL}$ of water) was added with stirring and white precipitate was immediately formed. The suspension was then prepared as described above.

\section{$Z n D$}

$\mathrm{Zn}\left(\mathrm{NO}_{3}\right)_{2} \cdot 6 \mathrm{H}_{2} \mathrm{O}(1.49 \mathrm{~g})$ dissolved in water $(50 \mathrm{~mL})$ was heated to $60{ }^{\circ} \mathrm{C}$. $\mathrm{Na}_{5} \mathrm{P}_{3} \mathrm{O}_{10}$ (0.74 g in $20 \mathrm{~mL}$ of water) was added while stirring and white precipitate was also immediately formed. The suspension was then prepared as described above. All prepared Zn NPs were subjected to sedimentation and washed with water to remove byproducts and free zinc ions. Finally, the rest of water was removed by lyophilization. For in vitro experiments, the samples were resuspended in water and for in vivo experiment, the lyophilized particles were added directly to the diet.

\section{Particle size and structural analysis}

The mean particle diameter and size distribution were determined by dynamic light scattering on a Malvern Zetasizer (NANO-ZS, Malvern Instruments Ltd., Worcestershire, UK).

Transmission electron microscopy (TEM) images of dried samples on copper grids were taken with a Tecnai F20 microscope (FEI, Eindhoven, Netherlands) at appropriate magnifications.

X-ray powder diffraction analysis (XRD) of zinc phosphates was carried out on D8 Advance ECO (Bruker, AXS GmbH, Karlsruhe, Germany). Bragg-Brentano geometry, $\mathrm{CuK} \alpha$ radiation $(\lambda=1.54178 \AA)$, the range of $2 \theta=4-60^{\circ}$ and room temperature were used for analysis.

\section{In vitro antibacterial testing}

The antibacterial effect of $\mathrm{Zn}$ NPs and $\mathrm{ZnO}$ was analyzed by: a) counting of bacterial colonies, b) live/dead assay, and c) bacterial growth curves. Escherichia coli NCTC 13216, Staphylococcus aureus NCTC 8511, and Methicillin-resistant S. aureus CCM 7110 (Czech Collection of Microorganisms, Brno, Czech Republic) were cultured in Muller-Hinton (MH) broth (Oxoid, Hampshire, UK) overnight at $37^{\circ} \mathrm{C}$ and shaking at $150 \mathrm{r} / \mathrm{min}$.

\section{Plating technique}

Bacterial suspensions at concentrations of $\sim 1.0 \times 10^{8}$ $\mathrm{CFU} / \mathrm{mL}$ (measured by optical density at $600 \mathrm{~nm}$ ) were serially diluted in tenfold steps in $\mathrm{MH}$ broth. A total of $900 \mu \mathrm{L}$ diluted bacterial cultures were mixed with $100 \mu \mathrm{L}$ of $\mathrm{Zn}$ NPs or $\mathrm{ZnO}$ at the final concentration of 5 $\mathrm{mmol} / \mathrm{L}$. After $2 \mathrm{~h}$ incubation at $37^{\circ} \mathrm{C}, 100 \mu \mathrm{L}$ of each inoculum was spread on $\mathrm{MH}$ agar and incubated for 24 $\mathrm{h}$ at $37^{\circ} \mathrm{C}$. The colony forming units (CFUs) were 
counted and compared and expressed in \% change to that of control samples.

\section{Live/dead assay}

The MRSA culture was incubated with $\mathrm{Zn}$ NPs or $\mathrm{ZnO}$ (as described above) and then centrifuged and washed with $0.85 \% \mathrm{NaCl}$. For the live/dead assay, fluorescent dyes, SYTO9 (Thermo Fisher Scientific, USA) and propidium iodide (PI; Sigma Aldrich, St. Louis, USA) were used and bacterial cells were observed on Olympus IX71 inverted fluorescence microscope (Olympus, Tokyo, Japan). The excitation wavelength was $460-495 \mathrm{~nm}$ for SYTO9 and 545-580 $\mathrm{nm}$ for PI.

\section{Growth curve method}

One hundred $\mu \mathrm{L}$ of each bacterial suspension $\left(\sim 1.0 \times 10^{6}\right.$ $\mathrm{CFU} / \mathrm{mL}$ ) was placed into a 96-well microplate and mixed with $\mathrm{Zn}$ NPs or $\mathrm{ZnO}$ in ratio 1:1 (total volume $200 \mu \mathrm{L}$ ). The bacterial growth was detected by Multiskan EX (Thermo Fisher Scientific, Bremen, Germany) using Ascent Software. The optical density reads at $620 \mathrm{~nm}$ were monitored at time zero, and then at $30 \mathrm{~min}$ intervals for $24 \mathrm{~h}$ at $37^{\circ} \mathrm{C}$.

\section{Animal feeding experiment}

The experiments were performed with the approval of the Ethics Commission at the Faculty of AgriSciences, Mendel University in Brno, Czech Republic in accordance with Act No. 246/1992 Coll. for the protection of animals against cruelty. Throughout the experiment, microclimatic conditions were maintained at $23 \pm 1{ }^{\circ} \mathrm{C}$, $60 \%$ humidity, and the light regime $(12 \mathrm{~h} \mathrm{~L}, 12 \mathrm{~h} \mathrm{D})$ with a maximum illumination of $200 \mathrm{~lx}$. Laboratory male rats of the outbred strain Wistar albino were used as model animals. Animals were divided into seven groups of ten rats each. Rat average initial weight was $144 \pm 2 \mathrm{~g}$. Four groups of rats were fed with phosphate-based zinc nanoparticles $(\mathrm{ZnA}, \mathrm{ZnB}, \mathrm{ZnC}, \mathrm{ZnD})$ in the dose of $2,000 \mathrm{mg}$ $\mathrm{Zn} / \mathrm{kg}$ diet. Fifth group was fed by commercial zinc nanoparticles $(\mathrm{ZnO}-\mathrm{N})$ in the dose $2,000 \mathrm{mg} \mathrm{Zn} / \mathrm{kg}$ diet. Sixth group was fed by $\mathrm{ZnO}$ in the dose of $2,000 \mathrm{mg} \mathrm{Zn} /$ $\mathrm{kg}$ diet. The last (control) group had no addition of $\mathrm{Zn}$ in their feed $(C)$. Animals were weighed at regular intervals (day $0,7,14,21$ and 28). All groups of rats had mono diet (wheat) with $2.7 \mathrm{mg} / \mathrm{kg}$ of $\mathrm{Zn}$. The experiment lasted for $28 \mathrm{~d}$. The animals had access to feed and drinking water ad libitum. At the end of the experiment, five animals from each group were put to death and blood, kidney, duodenum and liver samples were dissected out and used for chemical analyses. Samples for histopathology were fixed using 10\% formaldehyde.
$\mathrm{Zn}$ determination by atomic absorption spectrometry The digestion mixture was prepared in digestion vials and composed of $10.0 \mu \mathrm{L}$ of blood mixed with nitric acid suprapure $(300 \mu \mathrm{L})$ and $30 \%$ hydrogen peroxide $(200 \mu \mathrm{L})$. Samples were digested in the Microwave 3000 (Anton Paar $\mathrm{GmbH}$, Austria, with the power of $100 \mathrm{~W}$ ) for 30 $\min$ at $140{ }^{\circ} \mathrm{C}$. Homogenized liver and kidney $(500 \pm 0.1$ $\mathrm{mg}$ ) were decomposed using nitric acid suprapure $(5 \mathrm{~mL}), 30 \%$ hydrogen peroxide $(2 \mathrm{~mL})$, and deionized water $(3 \mathrm{~mL})$ as digestion mixture in MW Ethos ONE (Milestone, Italy) for $30 \mathrm{~min}$ at $210^{\circ} \mathrm{C} . \mathrm{Zn}$ was determined by the 240FS AA (Agilent Technologies, USA) atomic absorption spectrometer with deuterium background correction. The instrument operated under conditions recommended by manufacturer with airacethylene flame (flow rate $13.5 \mathrm{~L} / \mathrm{min}$ and $2.0 \mathrm{~L} / \mathrm{min}$ ) and $213.86 \mathrm{~nm}$ resonance line.

\section{Oxidative status determination Sample preparation}

Two grams of liver or kidney from each animal were homogenized in a friction bow with the addition of liquid nitrogen and $1.5 \mathrm{~mL}$ of water. For blood, $200.0 \mu \mathrm{L}$ of plasma with $0.5 \mathrm{~mL}$ of MilliQ was kept in liquid nitrogen for $2 \mathrm{~min}$. After homogenization, each sample was sonicated using an ultrasound needle for 2 min, shaken for $10 \mathrm{~min}$ (blood for $1 \mathrm{~min}$ ), and centrifuged for $20 \mathrm{~min}$ at $25,000 \times g$ at $4{ }^{\circ} \mathrm{C}$. One hundred $\mu \mathrm{L}$ of supernatant from each sample were mixed with $100 \mu \mathrm{L}$ of $10 \%$ TFA and centrifuged for $20 \mathrm{~min}$ at $25,000 \times g$ at $4{ }^{\circ} \mathrm{C}$. Supernatant was collected for the antioxidant activity analysis.

The BS-400 automated spectrophotometer (Mindray, China) was used for oxidative status analysis, specifically for TEAC (Trolox equivalent antioxidant capacity), DPPH (2,2-diphenyl-1-picrylhydrazyl), MDA (Malondialdehyde), and SOD (Superoxide dismutase).

\section{TEAC}

ABTS (2,2' -azino-bis(3-ethylbenzothiazoline-6-sulphonic acid) $(54.9 \mathrm{mg})$ was dissolved in $20.0 \mathrm{~mL}$ of phosphate buffer $(\mathrm{pH} 7.0 ; 5 \mathrm{mmol} / \mathrm{L})$ and activated to cation of ABTS + radical by addition of $\mathrm{MnO}_{2}(1.0 \mathrm{~g})$ under occasional stirring for $30 \mathrm{~min}$. Subsequently, $15.0 \mu \mathrm{L}$ of sample were added. Absorbance of solution was measured at $\lambda=734 \mathrm{~nm}$.

\section{$D P P H$}

A total of $150 \mu \mathrm{L}$ of $0.095 \mathrm{mmol} / \mathrm{L}$ 2,2-diphenyl-1-picrylhydrazyl was transferred into plastic cuvette with 15.0 $\mu \mathrm{L}$ of sample. Absorbance was measured for $12 \mathrm{~min}$ at $\lambda=505 \mathrm{~nm}$. To assess the production of free radicals, the difference in absorbance between the reagent with and without a sample was taken after the $10 \mathrm{~min}$ incubation period. 


\section{MDA}

Trichloroacetic acid was used because of its ability to precipitate proteins, bilirubin, unsaturated fatty acids and lipoproteins. Each sample $(300 \mu \mathrm{L})$ was mixed with $10 \mu \mathrm{L}$ of $0.5 \mathrm{~mol} / \mathrm{L}$ solution of butylated hydroxytoluene in $96 \%$ ethanol $(\nu / \nu)$ and $310 \mu \mathrm{L}$ of $20 \%$ trichloroacetic acid $(v / v)$ prepared in $0.6 \mathrm{~mol} / \mathrm{L} \mathrm{HCl}$. After $20 \mathrm{~min}$ incubation on ice, the mixture was centrifuged at $11,000 \times g$ for $15 \mathrm{~min}$. Subsequently, $400 \mu \mathrm{L}$ of the supernatant was mixed with $800 \mu \mathrm{L}$ of $30 \mathrm{mmol} / \mathrm{L}$ thiobarbituric acid and the mixture was incubated at $90^{\circ} \mathrm{C}$ for $30 \mathrm{~min}$. After cooling on ice, MDA absorbance was measured at 535 $\mathrm{nm}$ and the concentration was subtracted from the calibration curve.

\section{SOD}

The SOD Assay Kit was used for the superoxide dismutase analysis. A total of $200 \mu \mathrm{L}$ of the reagent R1 (WTS solution diluted 20 times in a buffer) was pipetted into a plastic cuvette and incubated at $37^{\circ} \mathrm{C}$ for $1.8 \mathrm{~min}$. Afterwards, each sample $(20 \mu \mathrm{L})$ was added and incubated for $6.3 \mathrm{~min}$. The reaction started by adding $20 \mu \mathrm{L}$ of the reagent R2 (enzyme solution 167 times diluted in a buffer) and this was incubated for $72 \mathrm{~s}$ and absorbance was then measured at $450 \mathrm{~nm}$.

\section{Reduced glutathione analysis}

The high-performance liquid chromatography with electrochemical detection (ESA Inc., Chelmsford, MA) was used for reduced glutathione (GSH) determination. Samples were analyzed in the chromatographic column with reverse phase Zorbax eclipse AAA C18 (Agilent Technologies, USA). The flow rate of mobile phase was 1.1 $\mathrm{mL} / \mathrm{min}$ and mobile phase consisted of A: trifluoroacetic acid $(80 \mathrm{mmol} / \mathrm{L})$ and B: $100 \%$ methanol. Compounds $(\mathrm{GSH})$ were eluted by following gradients: $0 \rightarrow 1 \mathrm{~min}$ $(4 \%$ B), $2 \rightarrow 5$ min (7\% B), $6 \rightarrow 10$ min (98\% B), $11 \rightarrow 20$ $\min (4 \% \mathrm{~B})$. Detection was carried out at applied potential $900 \mathrm{mV}$.

\section{Histopathology analysis}

Tissues were fixed individually in the $10 \%$ neutral buffered formaldehyde. Tissues sections were cut at $3.0 \mu \mathrm{m}$ and placed onto Superfrost Plus slides (Leica, UK) with the orientation core placed up on the slide. All sections were oriented the same way and the entire tissue block was cut with remaining sections dipped in wax and stored at the room temperature. The sections were stained with hematoxylin and eosin following standard procedures. Photographs were taken using an inverted Olympus microscope IX 71 S8F-3 (Tokyo, Japan).

\section{Analysis of the total aerobic bacteria and coliforms in feces}

The fecal samples were homogenized in sterile phosphate buffer solution (PBS) on ice $(1: 9 w / v)$ and the homogenate was serially diluted in PBS. Subsequently, $1.0 \mathrm{~mL}$ of diluted suspension was mixed with sterile molten Plate Count Agar (PCA) and MacConkey Agar (Sigma-Aldrich) in duplicates. The total colony counts from PCA and counts of coliforms from MacConkey Agar were enumerated after $24 \mathrm{~h}$ at $37^{\circ} \mathrm{C}$. The results are expressed as log (CFU/g) of feces.

\section{Descriptive statistics}

The data were processed statistically using STATISTICA.CZ, version 12.0 (Czech Republic). The results were expressed as the mean \pm standard deviation (SD). Statistical significance was determined using ANOVA and Scheffés test (one-way analysis). The analysis of total counts and coliforms in feces was performed using one-way ANOVA with post-hoc Dunnett's C test specialized for unequal variances and unequal sample sizes (IBM SPSS Statistics 21, Version 21.0. Armonk, NY, USA). The differences with $P<0.05$ were considered significant.

\section{Results}

\section{Zn NPs characterization}

In-house prepared particles were synthesized from various precursors - hydrogen phosphate ( $\mathrm{ZnA}$ and $\mathrm{ZnB})$, diphosphate $(\mathrm{ZnC})$, and triphosphate $(\mathrm{ZnD}) . \mathrm{ZnA}$ and $\mathrm{ZnB}$ particles had spherical shape with the average diameter 477 and $521 \mathrm{~nm}$, respectively (Fig. 1a and b). The other two types of particles, $\mathrm{ZnC}$ and $\mathrm{ZnD}$, were based on diphosphate and triphosphate salts. The effect of anions was much greater than that of cations. $\mathrm{ZnC}$ and $\mathrm{ZnD}$ had irregular shape with tendency to form small aggregates (Fig. 1c and d). The determined average diameter was estimated to $452(\mathrm{ZnC})$ and $1035(\mathrm{ZnD})$ $\mathrm{nm}$. The polydispersity indices of $\mathrm{ZnA}, \mathrm{ZnB}$ and $\mathrm{ZnC}$ particles were between $0.16-0.19$. The $\mathrm{ZnD}$ exhibited a higher polydispersity index (0.4) likely due to the formation of particles from the smaller parts (Fig. 1d).

Crystalline forms of samples allowed for their analysis by powder XRD and the identification of products by comparison with Powder Diffraction Files (PDF). For preparation of zinc phosphate, ammonium salts (ZnA) and sodium salts $(\mathrm{ZnB})$, were used. From XRD spectrum of $\mathrm{ZnA}$ it follows that using ammonium salt only hopeite $\mathrm{Zn}_{3}\left(\mathrm{PO}_{4}\right)_{2} \cdot 4 \mathrm{H}_{2} \mathrm{O}$ (PDF 37-0465) was obtained (Fig. 1e). When sodium salt $(\mathrm{ZnB})$ was used under the same conditions, $90 \%$ of product is hopeite but $10 \%$ was zinc phosphate dihydrate (PDF 41-0493, Fig. 1f). For ZnC preparation, diphosphate was applied and the product was identified as $\mathrm{Zn}_{2} \mathrm{P}_{2} \mathrm{O}_{7} \cdot 5 \mathrm{H}_{2} \mathrm{O}$ (PDF 07-0087, Fig. 1g). 

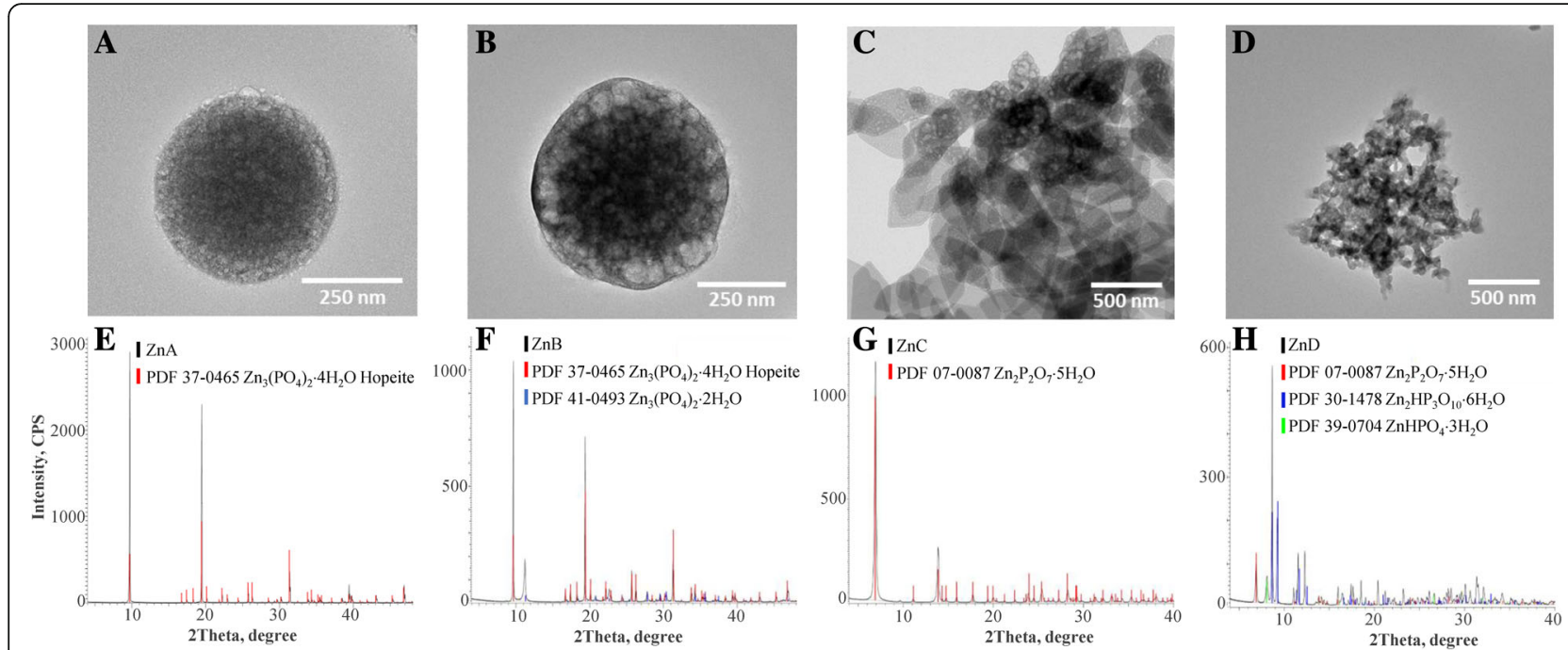

Fig. 1 The phosphate-based zinc NPs size and structural characteristics. TEM images of $\mathbf{a} Z n A, \mathbf{b} Z n B, \mathbf{c} Z n C$, and $\mathbf{d} Z n D$. The XRD spectra of e ZnA, $\mathbf{f}$ $\mathrm{ZnB}, \mathbf{g} \mathrm{ZnC}$, and $\mathbf{h} \mathrm{ZnD}$

More complicated situation occurred for $\mathrm{ZnD}$. XRD analysis of the spectrum showed a mixture of three products (Fig. 1h). The most abundant component $(60 \%)$ was as expected zinc triphosphate $\mathrm{Zn}_{2} \mathrm{HP}_{3} \mathrm{O}_{10} \cdot 6 \mathrm{H}_{2} \mathrm{O}$ (PDF 30-1478); however, there was also $\mathrm{Zn}_{2} \mathrm{P}_{2} \mathrm{O}_{7} \cdot 5 \mathrm{H}_{2} \mathrm{O}$ (07-0087) (30\%) and $\mathrm{ZnHPO}_{4} \cdot 3 \mathrm{H}_{2} \mathrm{O}$ (PDF 39-0704) (10\%). Nevertheless, considering the method of sodium triphosphate preparation, the final product had satisfactory composition for biological testing.

\section{In vitro antibacterial activity}

The following analyses were performed with in-house prepared $\mathrm{Zn} \mathrm{NPs}$ and commercial $\mathrm{ZnO}-\mathrm{N}$ and $\mathrm{ZnO}$ as control standards. The in vitro antibacterial effect of NPs was verified by three different techniques and the results are shown in Fig. 2. First, counts of viable bacteria after the $24 \mathrm{~h}$ incubation period with $5 \mathrm{mmol} / \mathrm{L}$ $\mathrm{Zn} \mathrm{NPs} \mathrm{and} \mathrm{ZnO}$ were determined (Fig. 2a). ZnA and $\mathrm{ZnO}$ greatly effected the growth of $E$. coli $(99.6 \%$ inhibition with $\mathrm{ZnA} ; 98.5 \%$ inhibition with $\mathrm{ZnO}$ ) and $\mathrm{ZnB}$ inhibited $E$. coli completely. In contrast, $\mathrm{ZnC}$ had no effect on $E$. coli growth. All types of $\mathrm{Zn} \mathrm{NPs}$ and $\mathrm{ZnO}$ caused $>97 \%$ inhibition of $S$. aureus. The spread-plate technique also showed that the reduction of MRSA was lower than that of $S$. aureus (Fig. 2b). The formation of viable colonies was suppressed after $\mathrm{Zn}$ NPs and $\mathrm{ZnO}$ exposure. The MRSA fluorescence images (Fig. 2c) are in a good agreement with the previous experiment. Images also demonstrate that $\mathrm{ZnA}, \mathrm{ZnB}$, and $\mathrm{ZnO}-\mathrm{N}$, and $\mathrm{ZnO}$ inhibited the growth of bacteria (green fluorescence). Although $\mathrm{ZnC}$ and $\mathrm{ZnD}$ did not significantly suppress bacterial proliferation, the amount of dead cells (red fluorescence) increased substantially.
The inhibitory effect (in \%) of final $\mathrm{Zn}$ concentrations $0.15-5 \mathrm{mmol} / \mathrm{L}$ after $16 \mathrm{~h}$ was obtained (Fig. $2 \mathrm{~d}-\mathrm{f}$ ) from the growth curves. The maximum inhibitory concentrations for E. coli (Fig. 2d) varied between $1.25-2.5 \mathrm{mmol} /$ L. Interestingly, with the exception of $\mathrm{ZnA}$ and $\mathrm{ZnB}$, the inhibitory effect of NPs decreased by increasing the $\mathrm{Zn}$ concentrations. In fact, the $5.0 \mathrm{mmol} / \mathrm{L} \mathrm{ZnC}$ treatment had almost no effect on $E$. coli growth. For $S$. aureus (Fig. 2e), the highest inhibition was also observed in the range of $1.25-2.5 \mathrm{mmol} / \mathrm{L}$ of $\mathrm{Zn}$, but the inhibition decline at $5 \mathrm{mmol} / \mathrm{L}$ was not as high as that for E. coli. Inhibition of MRSA (Fig. 2f) by Zn NPs (with the exception of $\mathrm{ZnC}$ and $\mathrm{ZnO}$ ) were different from that of other bacterial strains. The overall comparison of antimicrobial activity using the 50\% inhibitory concentration $\left(\mathrm{IC}_{50}\right)$ is shown in Table 1.

\section{Antioxidant status of rats}

The levels of $\mathrm{Zn}, \mathrm{MDA}, \mathrm{GSH}, \mathrm{SOD}$, and overall antioxidant activity indicated the impact of Zn NPs and zinc oxide treatments on the rat liver, kidney, and blood (Fig. 3). The average $\mathrm{Zn}$ levels upon treatment were $75.2 \pm 4.1 \mathrm{mg} /$ $\mathrm{kg}$ in liver, $48.4 \pm 6.2 \mathrm{mg} / \mathrm{kg}$ in kidney and $10.3 \pm 4.1 \mathrm{mg} /$ $\mathrm{kg}$ in blood (Fig. 3a). The liver and kidney Zn concentration significantly increased $(P<0.05)$ in all treated groups compared to non-treated control group. In blood, the significant increase $(P<0.05)$ of zinc level was observed only after treatment with $\mathrm{ZnO}-\mathrm{N}$ and $\mathrm{ZnO}$. Results of DPPH and TEAC assays were compared to antioxidant activity of the trolox equivalent as a standard. DPPH method showed increased antioxidant activity in kidney compared to that in blood and liver. Treatments with $\mathrm{ZnA}, \mathrm{ZnB}$, $\mathrm{ZnO}-\mathrm{N}$ resulted in the significantly higher antioxidant 

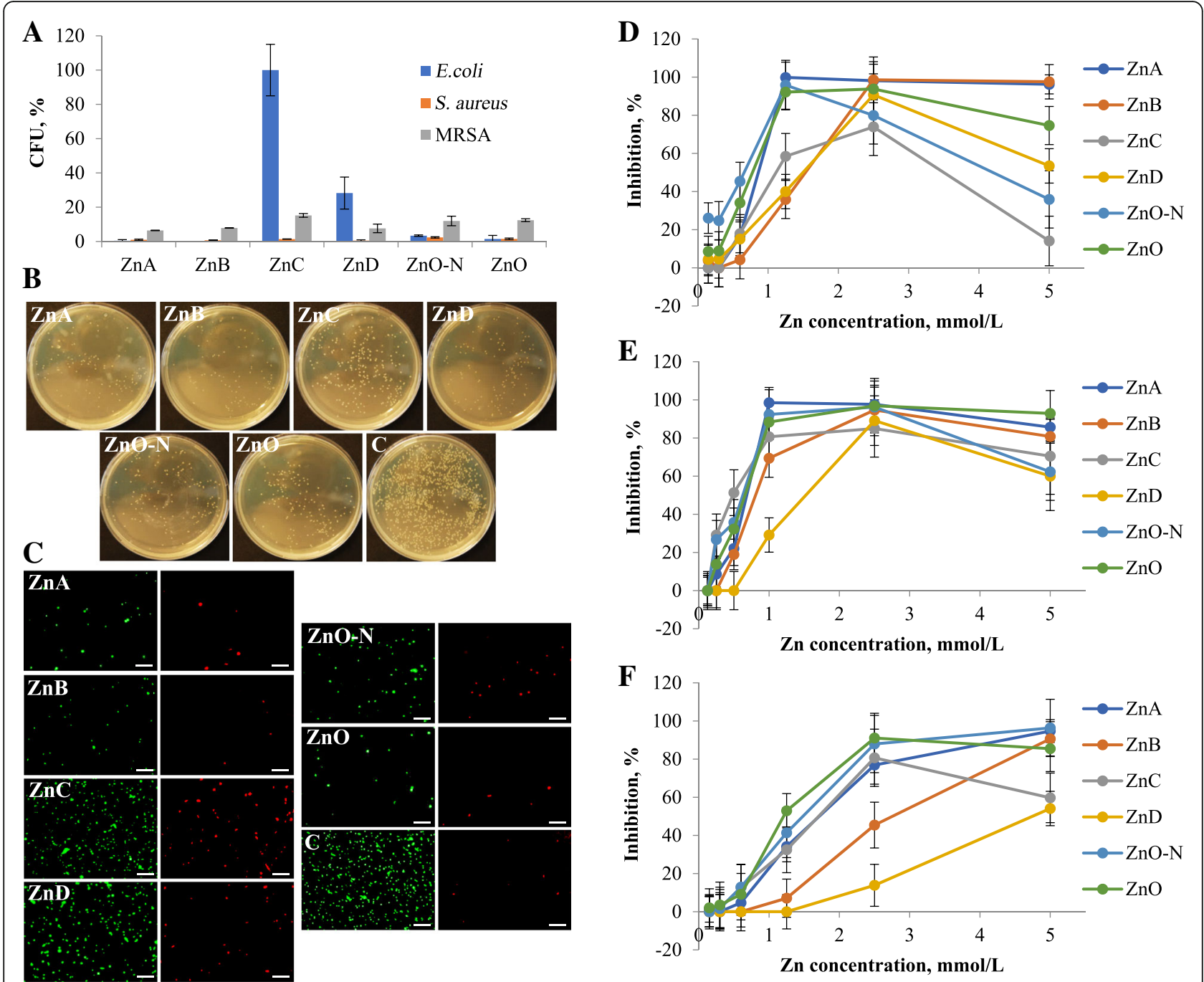

Fig. 2 In vitro Zn NPs and ZnO antibacterial testing. a Bacterial counts after $24 \mathrm{~h}$ cultivation with $5 \mathrm{mmol} / \mathrm{L}$ zinc compounds. b Digital photographs of MRSA colonies on plates. c Fluorescence microscopy of live and dead cells (SYTO 9, green) and dead cells (PI, red), scale bar is $20 \mu \mathrm{m}$. The $\mathrm{Zn}$ NPs and ZnO inhibition effect on $\mathbf{d}$ E. coli, e S. aureus, and $\mathbf{f}$ MRSA (mean $\pm \mathrm{SD}, n=3$ )

activity in kidney when compared to that of the control $(P<0.05)$. In liver, the significant reduction $(P<0.05)$ of antioxidant activity was detected after treatments with $\mathrm{ZnA}, \mathrm{ZnB}, \mathrm{ZnD}$ in comparison to that of control (no treatment). The lowest antioxidant activity was revealed in the blood and this did not differ across samples of all $\mathrm{Zn}$

Table 1 The $I C_{50}$ values, $\mathrm{mmol} / \mathrm{L}$, comparison

\begin{tabular}{llll}
\hline & E. coli & S. aureus & MRSA \\
\hline ZnA & 0.90 & 0.68 & 1.60 \\
ZnB & 1.50 & 0.80 & 2.70 \\
ZnC & 1.10 & 0.48 & 1.60 \\
ZnD & 1.50 & 1.60 & 4.70 \\
ZnO-N & 0.70 & 0.62 & 1.45 \\
ZnO & 0.80 & 0.66 & 1.20 \\
\hline
\end{tabular}

formulations (Fig. 3b). Based on TEAC method, the antioxidant activity of blood $(5.8 \pm 0.2 \mathrm{TE} \mathrm{ng} / \mathrm{mL})$ and liver $(24.9 \pm 3.3 \mathrm{TE} \mathrm{ng} / \mathrm{mL})$ was stable across all $\mathrm{Zn}$ formulations as well as controls. In kidneys (Fig. 3c), the antioxidant activity of all $\mathrm{Zn}$ variants was significantly $(P<0.05)$ higher (up to $14.4 \pm 1.0 \mathrm{TE} \mathrm{ng} / \mathrm{mL}$ ) than in control $(6.3 \pm$ $1.1 \mathrm{TE} \mathrm{ng} / \mathrm{mL}$ ). The highest SOD activity was recorded in the blood at 4,000 $\pm 100 \mathrm{U} / \mathrm{L}$. For liver and kidney, the enzyme activity was $2000 \pm 500 \mathrm{U} / \mathrm{L}$. Individual formulations of $\mathrm{Zn}$ did not influence the enzymatic activity of SOD when compared to that of samples with no $\mathrm{Zn}$ treatment (Fig. 3d). Levels of GSH reflected the whole protein concentration. In liver, GSH concentrations significantly $(P<0.05)$ increased in all $\mathrm{Zn}$ treated groups. Overall, it was clear that all $\mathrm{Zn}$ formulations had different effects on the GSH levels in the blood and kidney (Fig. 3e). MDA concentrations were $0.23 \pm 0.05 \mu \mathrm{mol} / \mathrm{L}$ (blood), $1.2 \pm$ 

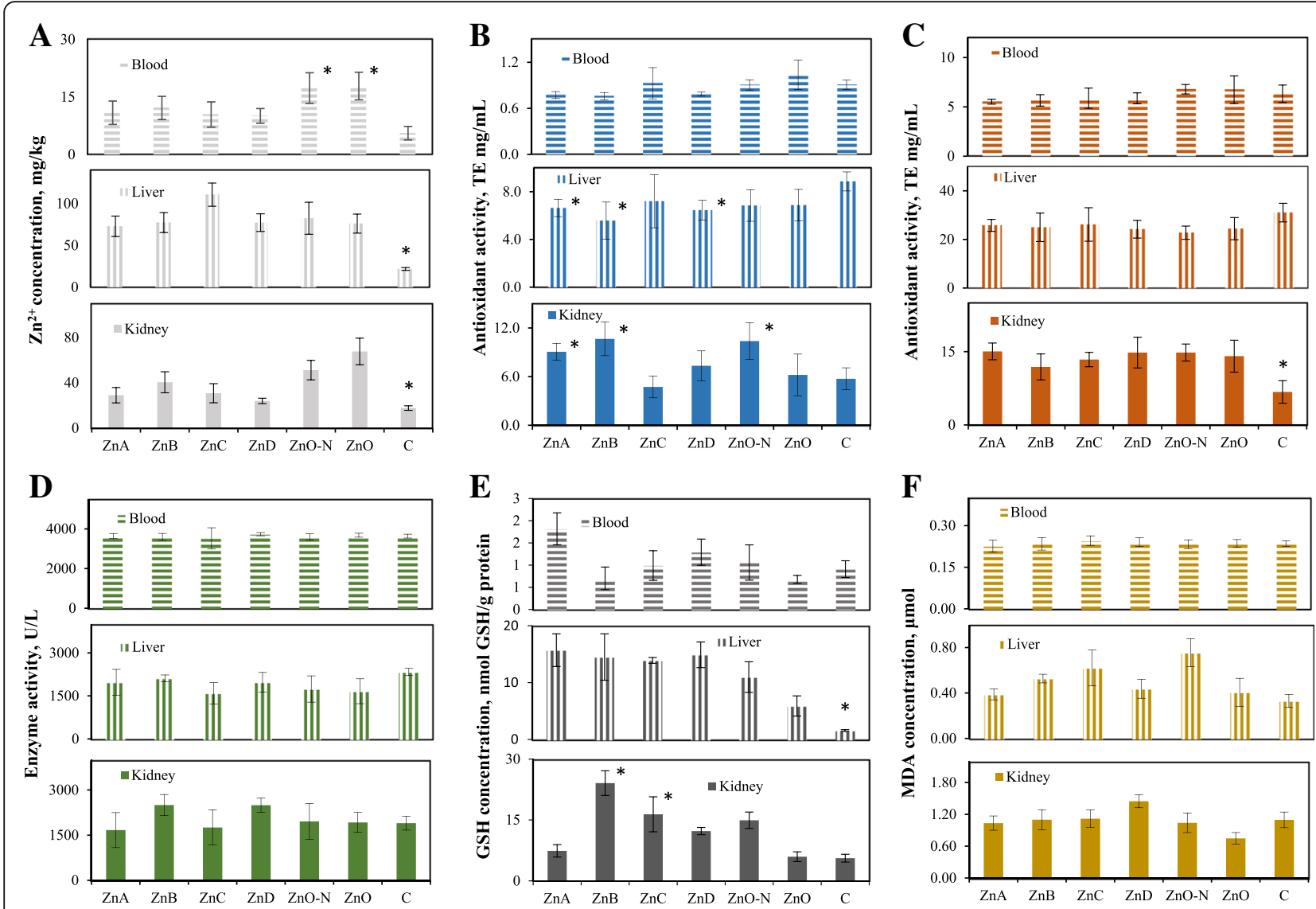

Fig. 3 Levels of Zn and antioxidant system status in rat organism. a Zn concentration in blood, liver, and kidney. Antioxidant activities determined in blood, liver, and kidney using $\mathbf{b}$ DPPH and $\mathbf{c}$ TEAC methods. Results are expressed as mg/mL of Trolox equivalent. $\mathbf{d}$ Enzymatic activity of SOD. e Levels of GSH. Results are related to the protein content. $\mathbf{f}$ Concentration of MDA in blood, liver, kidney. ${ }^{*}$ Mean values were significantly different $(P<0.05)$

$0.1 \mu \mathrm{mol} / \mathrm{L}$ (kidney), and $0.6 \pm 0.1 \mu \mathrm{mol} / \mathrm{L}$ (liver) (Fig. 3f). No significant difference $(P>0.05)$ was detected.

\section{Histology of liver and duodenum and rat growth}

The histological evaluation of the rat liver and small intestine (duodenum) was performed to assess possible negative effects of zinc treatments on these organs (see Additional file 1: Figure S2). Liver parenchyma of the rats fed with $\mathrm{ZnA}$ showed intact structure without necrosis and inflammation (Additional file 1: Figure S2A). Occasionally, the centrosocial districts of unstable steatal dystrophy were observed. Examination of the intestine showed the autolysis disintegration of the apical segments of the villus. Enterocytes were normal and more frequent occurrence of the cup cells was observed (Additional file 1: Figure S2B). In the $\mathrm{ZnB}$ group, heavy hepatodystrophy was seen in the liver. Portobilia was dilated with small groups of lymphocytic cellulization (Additional file 1: Figure S2C). In the intestine, the autologous disintegration of the apical segments of the villus (Additional file 1: Figure S2D) was also observed. Liver parenchyma of $\mathrm{ZnC}$ treated rats showed hepatodystrophy across the hepatic parenchyma (Additional file 1: Figure S2E). In intestine, deformed intestinal villi were observed, followed by an increase of epithelial cup cells and traces of inflammation (Additional file 1: Figure S2F) were visible in the stroma. Group of $\mathrm{ZnD}$ treated rats showed full-length hepatodystrophy in the liver parenchyma (Additional file 1: Figure S2G) and the intestine had hypertrophied and deformed villi. Many cup cells in the epithelium and numerous mitoses in the lining crypt were also seen (Additional file 1: Figure S2H). Treatment with commercial ZnO-N caused full-length, prolonged cholestatic hepatodystrophy in the liver (Additional file 1: Figure S2I). The intestine underwent focal autolytic disintegration of the mucosa and the villi were hypertrophied. In the lining of the crypts, a higher incidence of cup cells, numerous mitoses and mild inflammation in the cluster stroma were detected (Additional file 1: Figure S2J). Furthermore, the $\mathrm{ZnO}$ rat group exhibited a full-length mixed hepatodystrophy of the liver (Additional file 1: Figure S2K). The intestine in this group showed mild autolytic damage to the lining of the intestinal 
mucosa although intact regions were also found (Additional file 1: Figure S2L). Liver parenchyma of the control group (non-treated group) showed all-surface hepatodystrophy with significant portobiliary dilation (Additional file 1: Figure S2M). Intestinal samples showed destruction of apical parts of the cartilage, mild autolytic lesion damage, numerous cup cells in crypts, sparse and lymphocytic cellulization in the stroma of the cartilage (Additional file 1: Figure S2N).

Experimental rats were regularly weighted $(0,7,14,21$, $28 \mathrm{~d}$ ). The initial weight of all groups was in the range $130.0-155.0 \mathrm{~g}$. The weight results were comparable in all groups both at the beginning and at the end of the experiment (see Additional file 1: Table S1). Only, the group $\mathrm{ZnB}$ showed an accelerated weight gain in comparison to that of all other groups at the end of the experiment.

\section{Effects of Zn NPs on total aerobic bacteria and coliforms} in feces

The counts of total aerobic and coliform bacteria in rat feces at day 10 and day 30 of each treatment are shown in Fig. 4. After $10 \mathrm{~d}$, the CFU levels from treated rats were not significantly different $(P>0.05)$ from that of the untreated control group. Interestingly, the ZnA group had the lowest CFU levels of both, total counts and coliforms. At day 30, all $\mathrm{Zn} \mathrm{NPs} \mathrm{and} \mathrm{ZnO}$ treatments resulted in the significant decrease of the total aerobic and coliform bacteria $(P<0.05)$ compared to the control group, with the exception of $\mathrm{ZnB}$ in total aerobic bacteria $(P>0.05$; Fig. 4b). Moreover, a significant decrease of coliforms $(P<0.05)$ was observed in rats exposed to $\mathrm{ZnA}$ and $\mathrm{ZnC}$ treatments compared to that of the $\mathrm{ZnO}$ group (Fig. $4 \mathrm{~d}$ ).
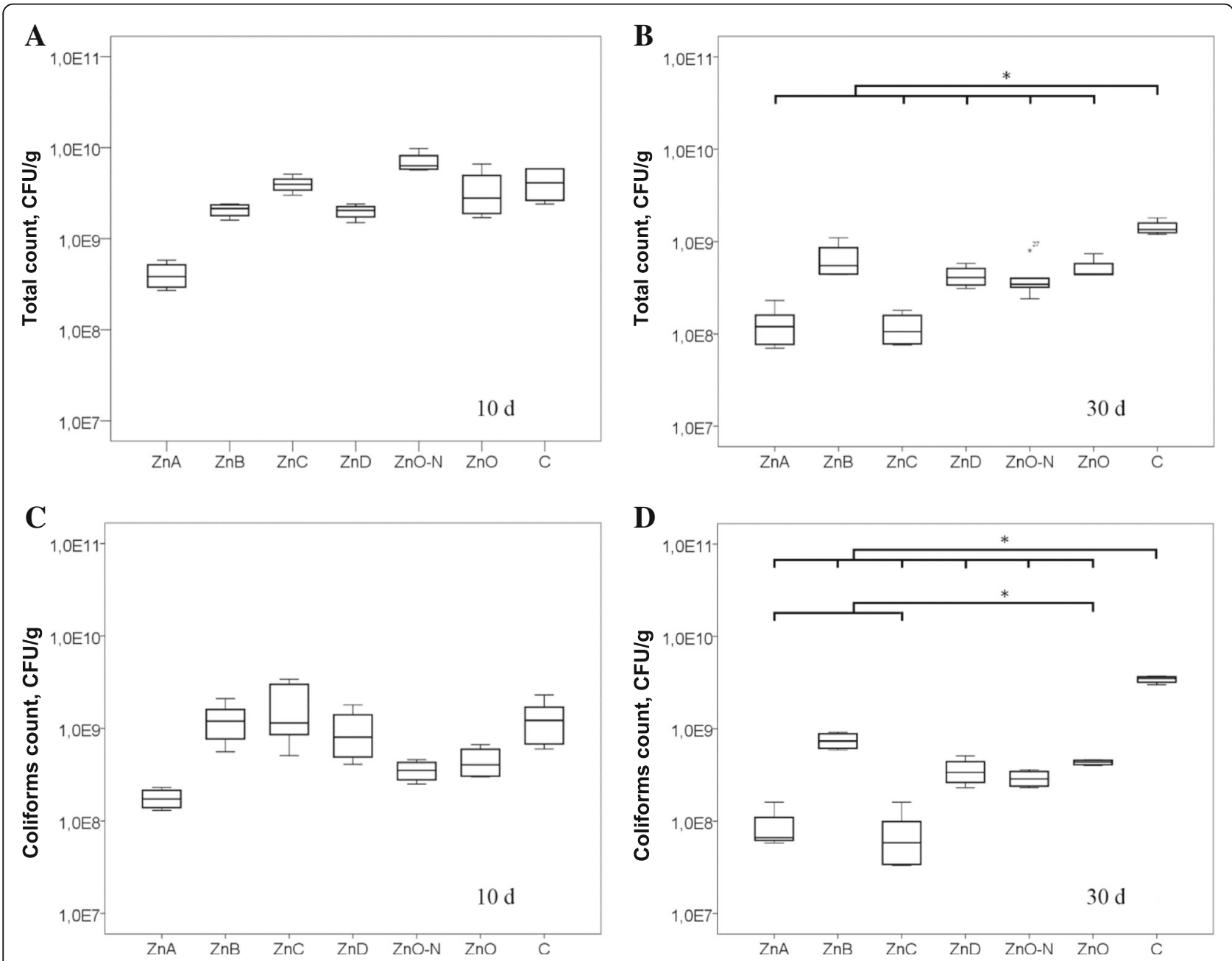

Fig. 4 Effects of $Z n N P s$ and $Z n O$ on bacteria in feces. Total bacterial counts after $\mathbf{a} 10 \mathrm{~d}$ and $\mathbf{b} 30 \mathrm{~d}$, counts of coliform bacteria after $\mathbf{c} 10 \mathrm{~d}$ and d $30 \mathrm{~d}$ of treatment (mean $\pm \mathrm{SD}, n=4)$. *Mean values were significantly different $(P<0.05)$ 


\section{Discussion}

Zinc compounds are well known for their antimicrobial properties [15, 22, 23] where zinc-based antibacterial nanoparticles occupy a very important place. Recently, zinc oxide nanoparticles gained substantial scientific interest worldwide [24]. Their role as antibacterial agents has been studied in details in terms of particle size and morphology, surface modification, photocatalytic activity, and ROS generation [25-28]. However, there is some evidence that zinc phosphate-based materials show antibacterial effect as well [29, 30], and the combination with nanotechnologies could be useful. Here, we investigated antibacterial activity of zinc phosphate-based nanoparticles and compared them with commercial $\mathrm{ZnO}$ and $\mathrm{ZnO}$ NPs. We found that all four Zn NPs formulations inhibited bacterial growth in vitro of both, Gram-negative and Gram-positive bacteria. In some cases, the optical density measurements showed that high $\mathrm{Zn}$ concentrations $(2.5-5 \mathrm{mmol} / \mathrm{L})$ resulted in lower bacterial inhibition. This phenomenon was the most obvious for $E$. coli and this was also confirmed by the bacterial counts when the $5.0 \mathrm{mmol} / \mathrm{L} \mathrm{Zn} \mathrm{concentra-}$ tion was used. The lower antibacterial response to high $\mathrm{Zn}$ concentrations may due to reduced solubility [31]. The low $\mathrm{Zn}$ doses can be even beneficial for bacterial growth and used as essential trace elements [32, 33]. Consequently, determination of the appropriate Zn NPs dosage is crucial for further applications. The different $\mathrm{IC}_{50}$ values between Gram-negative and Gram-positive bacteria implies interactions of zinc-based nanoparticles with the bacterial cell wall [34]. Moreover, the Gramnegative bacteria possess, in addition to a complex and poorly penetrable outer membrane, an advanced efflux system for removal of foreign compounds [35]. Interestingly, the lowest sensitivity to Zn NPs was found in MRSA. Unlike susceptible $S$. aureus, the MRSA genome contains the unique staphylococcal chromosomal cassette element SCCmec. This mobile genetic element includes mec genes, that encode resistance to $\beta$-lactams antibiotics [36, 37]. Importantly, the SCCmec cassette is also associated with metal resistance and there are several studies describing the presence of the zinc resistance gene $(c z r C)$ on the SCCmec element [38-40].

The antioxidant status of rat kidney, liver and blood was determined after zinc NPs treatments. In general, zinc acts as an antioxidant in an organism. The highest zinc accumulation was observed in liver, which plays a crucial role in zinc homeostasis regulation $[41,42]$. The $\mathrm{Zn}$ concentrations in liver and kidney elevated after the treatment with all Zn NPs formulations. This is in line with the results presented by Baek et al., who found the highest accumulation of $\mathrm{ZnO}$ NPs in liver and kidney without any influence of rat gender or NPs size [43]. Moreover, this phenomenon (distribution of Zn NPs into liver and kidney after oral administration) has been described in a number of studies [44-46]. The total antioxidant activity was monitored by TEAC and DPPH methods. Our results confirmed that the most antioxidant activity was in kidney and liver, where the most important antioxidant processes take place. Jemai et al. [47] observed an increase of antioxidant activity in rat organs after zinc administration in concentration $4.0 \mathrm{mg} / \mathrm{kg}$ of body mass. Our study shows an increase of antioxidant activity compared to that of control by $\mathrm{ZnA}, \mathrm{ZnB}, \mathrm{ZnO}-\mathrm{N}$ in liver and kidney. SOD activity was constant across different zinc formulations. These data correlate with the concentration of glutathione (GSH). It is assumed that normal range SOD and GSH is $7-22 \mathrm{U} / \mathrm{mg}$ and $20-30 \mathrm{nmol} /$ L, respectively [48]. Another indicator of oxidative stress was the concentration of MDA where significantly elevated values were recorded after $\mathrm{ZnC}$ and $\mathrm{ZnO}-\mathrm{N}$ treatments. All other values measured in blood, liver and kidneys were normal. Overall, it is clear that zinc formulations did not influence the rat antioxidant status. Our results are in concordance with Liu et al. [49]. On the contrary, Zn NPs are known to be capable of ROS production leading to oxidative stress [50-52]. A strong relationship between released $\mathrm{Zn}$ ions and ROS induced cytotoxicity has been reported in the literature [53-55]. Histological analysis showed the flat liver damage in treated and non-treated control rats. This phenomenon was likely caused by the mono diet or stress. The most damage was observed in a group of animals fed with $\mathrm{ZnO}-\mathrm{N}$ and $\mathrm{ZnC}$, although recent studies revealed that zinc and zinc nanoparticles have some protective effect on the liver [56-59].

To investigate Zn NPs effect on host-colonizing bacteria, the population of total aerobic bacteria and coliforms in rat feces was analyzed. Lee and co-workers tracked orally administered $\mathrm{ZnO}$ NPs and after few hours of the exposure, the particles were mainly localized in the rat gastrointestinal tract [60]. Therefore, Zn NPs should be able to influence gut microbiota and the interaction of nanoparticles with the gut microbial community is discussed in several recent studies [61-64]. Our study demonstrated that dietary supplementation of rats with phosphate-based Zn NPs altered the bacterial population in feces as well. Due to inconsistent results in the control group the bacterial count decline was not significant at day 10; however, over time, the bacterial count was clearly reduced. Besides the number of bacteria, administration to Zn NPs affected the intestinal microbiome diversity, as well [65]. This phenomenon is in agreement with the work by Feng et al., suggesting that the ileal bacterial community richness decreased in response to higher dose of $\mathrm{ZnO}$ NPs $(100 \mathrm{mg} / \mathrm{kg})$, and that Lactobacillus genus was reduced in particular [66]. On the contrary, Li et al. pointed 
out, that $\mathrm{ZnO}$ NPs could act anti-inflammatory in a dose-dependent manner. This may be associated with reduction of infection-causing bacteria and, vice versa, gain of probiotics (Lactobacillus and Bifidobacterium) in colon [67].

\section{Conclusions}

In this study, four formulations of phosphate-based zinc nanoparticles were synthetized and tested. All four formulations exhibited antibacterial activity against Gram-positive and Gram-negative bacteria. The in vivo study on rats confirmed that in-house prepared zinc nanoparticles did not cause oxidative stress and changes in liver and duodenum tissues were comparable to that of the group treated with commonly used $\mathrm{ZnO}$. The effect our $\mathrm{Zn}$ formulations on the rat microbiome was similar to that caused by $\mathrm{ZnO}$. In fact, $\mathrm{ZnA}$ and $\mathrm{ZnC}$ nanoparticles caused even greater inhibition of coliform bacteria than $\mathrm{ZnO}$. Therefore, these nanoparticles have a potential to be used as new antibacterial agents, especially for reduction of coliform bacteria. Further studies, primarily focused on Zn NPs applications in livestock productions, are warranted.

\section{Additional file}

Additional file 1: Figure S1. TEM image of commercial ZnO-N. Figure S2. Histological analysis of liver (1) and duodenum (2) of the groups rats ZnA (A, B); ZnB (C, D); ZnC (E, F); ZnD (G, H); ZnO-N (I, J); ZnO (K, L) and control group (M, N). Table S1. The weight of rats, g. (DOCX $2889 \mathrm{~kb})$

\section{Abbreviations \\ ABTS: 2,2'-azino-bis(3-ethylbenzothiazoline-6-sulphonic acid); C: Control: CFU: Colony forming unit; DPPH: 2,2-diphenyl-1-picrylhydrazyl; GSH: Reduced glutathione; MDA: Malondialdehyde; MH: Muller-Hinton; MRSA: Methicillin resistant Staphylococcus aureus; NPs: Nanoparticles; PBS: Phosphate buffer solution; PCA: Plate count agar; PDF: Powder diffraction files; PI: Propidium iodide; ROS: Reactive oxygen species; SCC: Staphylococcal cassette chromosome element; SOD: Superoxide dismutase; TEAC: Trolox equivalent antioxidant capacity; TEM: Transmission electron microscopy; XRD: X-ray powder diffraction}

\section{Funding}

Financial support from ERDF "Multidisciplinary research to increase application potential of nanomaterials in agricultural practice" (No. CZ.02.1.01/0.0/0.0/16_025/0007314) is gratefully acknowledged. This study was also supported by NAZV QK1720349 "Nanoparticles zinc as an alternative to antibiotics in pigs", and AF-IGA-2018-tym001 "Comparison of the impact of climate change on photosynthesis C3 and C4 plants cycles which are used in livestock feed".

\section{Availability of data and materials}

All data generated or analysed during this study are included in this published article (and its supplementary information files).

\section{Authors' contributions}

PH and KS designed the study. MG, VM, DH and PK synthesized and characterized the nanoparticles. SK, ZB, and EK performed the microbiological analyses. SS, LU, and DB realized the animal experiments. VS, $\mathrm{ZL}, \mathrm{NC}$, and OK worked on oxidative status and zinc levels determination. EV, PN, PK analyzed data. JS and VA edited the manuscript. KS and PH wrote the manuscript. All the authors read and approved the final manuscript.

\section{Ethics approval}

All animal management and experiments were performed with the approval of the Ethics Commission at the Faculty of Agrisciences, Mendel University in Brno, Czech Republic in accordance with Act No. 246/1992 Coll. on the protection of animals against cruelty.

Consent for publication

Not applicable.

\section{Competing interests}

The authors declare that they have no competing interests.

\section{Author details}

'Department of Animal Nutrition and Forage Production, Mendel University in Brno, Zemedelska 1, CZ-613 00 Brno, Czech Republic. 'Department of Chemistry and Biochemistry, Mendel University in Brno, Zemedelska 1, CZ-613 00 Brno, Czech Republic. ${ }^{3}$ Central European Institute of Technology, Brno University of Technology, Purkynova 123, CZ-612 00 Brno, Czech Republic. Institute of Animal Science, Komenskeho 1239, CZ-517 41 Kostelec nad Orlici, Czech Republic. ${ }^{5}$ Department of Animal Breeding, Mendel University in Brno, Zemedelska 1, CZ-613 00 Brno, Czech Republic.

Received: 12 October 2018 Accepted: 9 January 2019

Published online: 12 February 2019

\section{References}

1. Dapkekar A, Deshpande P, Oak MD, Paknikar KM, Rajwade JM. Zinc use efficiency is enhanced in wheat through nanofertilization. Sci Rep. 2018;8:7.

2. Hagedorn K, Li WY, Liang QJ, Dilger S, Noebels M, Wagner MR, et al. Catalytically doped semiconductors for chemical gas sensing: aerogel-like aluminum-containing zinc oxide materials prepared in the gas phase. Adv Funct Mater. 2016;26(20):3424-37.

3. Shaheen TI, El-Naggar ME, Abdelgawad AM, Hebeish A. Durable antibacterial and UV protections of in situ synthesized zinc oxide nanoparticles onto cotton fabrics. Int J Biol Macromol. 2016;83:426-32.

4. Al-Naamani L, Dobretsov S, Dutta J. Chitosan-zinc oxide nanoparticle composite coating for active food packaging applications. Innov Food Sci Emerg Technol. 2016;38:231-7.

5. Javed MS, Chen J, Chen L, Xi Y, Zhang CL, Wan BY, et al. Flexible full-solid state supercapacitors based on zinc sulfide spheres growing on carbon textile with superior charge storage. J Mater Chem A. 2016;4(2):667-74.

6. Wang C, Zhang LG, Su WP, Ying ZX, He JT, Zhang LL, et al. Zinc oxide nanoparticles as a substitute for zinc oxide or colistin sulfate: effects on growth, serum enzymes, zinc deposition, intestinal morphology and epithelial barrier in weaned piglets. PLoS One. 2017;12(7):14.

7. Kaviyarasu K, Geetha N, Kanimozhi K, Magdalane CM, Sivaranjani S, Ayeshamariam A, et al. In vitro cytotoxicity effect and antibacterial performance of human lung epithelial cells A549 activity of zinc oxide doped $\mathrm{TiO}_{2}$ nanocrystals: investigation of bio-medical application by chemical method. Mater Sci Eng C-Mater Biol Appl. 2017;74:325-33.

8. Shankar S, Rhim JW. Facile approach for large-scale production of metal and metal oxide nanoparticles and preparation of antibacterial cotton pads. Carbohydr Polym. 2017;163:137-45.

9. Oun AA, Rhim JW. Carrageenan-based hydrogels and films: effect of $\mathrm{ZnO}$ and $\mathrm{CuO}$ nanoparticles on the physical, mechanical, and antimicrobial properties. Food Hydrocoll. 2017;67:45-53.

10. Premanathan M, Karthikeyan K, Jeyasubramanian K, Manivannan G. Selective toxicity of ZnO nanoparticles toward Gram-positive bacteria and cancer cells by apoptosis through lipid peroxidation. Nanomed-Nanotechnol Biol Med. 2011;7(2):184-92.

11. Xie YP, He YP, Irwin PL, Jin T, Shi XM. Antibacterial activity and mechanism of action of zinc oxide nanoparticles against Campylobacter jejuni. Appl Environ Microbiol. 2011;77(7):2325-31.

12. Alves MM, Bouchami O, Tavares A, Cordoba L, Santos CF, Miragaia M, et al. New insights into antibiofilm effect of a nanosized $\mathrm{ZnO}$ coating against the pathogenic methicillin resistant Staphylococcus aureus. ACS Appl Mater Interfaces. 2017;9(34):28157-67.

13. Hameed ASH, Karthikeyan C, Ahamed AP, Thajuddin N, Alharbi NS, Alharbi $\mathrm{SA}$, et al. In vitro antibacterial activity of $\mathrm{ZnO}$ and $\mathrm{Nd}$ doped $\mathrm{ZnO}$ nanoparticles against ESBL producing Escherichia coli and Klebsiella pneumoniae. Sci Rep. 2016;6:11. 
14. Chen CW, Hsu CY, Lai SM, Syu WJ, Wang TY, Lai PS. Metal nanobullets for multidrug resistant bacteria and biofilms. Adv Drug Deliv Rev. 2014;78:88104.

15. Abu Ali H, Shalash AM, Akkawi M, Jaber S. Synthesis, characterization and in vitro biological activity of new zinc (II) complexes of the nonsteroidal antiinflammatory drug sulindac and nitrogen-donor ligands. Appl Organomet Chem. 2017;31(11):14.

16. Jiang $Y H$, Zhang $L L$, Wen DS, Ding $Y L$. Role of physical and chemical interactions in the antibacterial behavior of $\mathrm{ZnO}$ nanoparticles against $E$. Coli. Mater Sci Eng C-Mater Biol Appl. 2016;69:1361-6.

17. Cai Q, Gao YY, Gao TY, Lan S, Simalou O, Zhou XY, et al. Insight into biological effects of zinc oxide nanoflowers on bacteria: why morphology matters. ACS Appl Mater Interfaces. 2016;8(16):10109-20.

18. Jain A, Bhargava R, Poddar P. Probing interaction of gram-positive and Gram-negative bacterial cells with ZnO nanorods. Mater Sci Eng C-Mater Biol Appl. 2013;33(3):1247-53

19. Heim J, Felder E, Tahir MN, Kaltbeitzel A, Heinrich UR, Brochhausen C, et al. Genotoxic effects of zinc oxide nanoparticles. Nanoscale. 2015;7(19):8931-8.

20. Bondarenko O, Juganson K, Ivask A, Kasemets K, Mortimer M, Kahru A. Toxicity of ag, $\mathrm{CuO}$ and $\mathrm{ZnO}$ nanoparticles to selected environmentally relevant test organisms and mammalian cells in vitro: a critical review. Arch Toxicol. 2013;87(7):1181-200.

21. Xia T, Kovochich M, Liong M, Madler L, Gilbert B, Shi HB, et al. Comparison of the mechanism of toxicity of zinc oxide and cerium oxide nanoparticles based on dissolution and oxidative stress properties. ACS Nano. 2008;2(10):2121-34.

22. Jiao LF, Lin FH, Cao ST, Wang CC, Wu H, Shu MA, et al. Preparation, characterization, antimicrobial and cytotoxicity studies of copper/zincloaded montmorillonite. J Anim Sci Biotechnol. 2017:8:27.

23. Pati R, Sahu R, Panda J, Sonawane A. Encapsulation of zinc-rifampicin complex into transferrin-conjugated silver quantum-dots improves its antimycobacterial activity and stability and facilitates drug delivery into macrophages. Sci Rep. 2016;6:24184.

24. Sirelkhatim A, Mahmud S, Seeni A, Kaus NHM, Ann LC, Bakhori SKM, et al. Review on zinc oxide nanoparticles: antibacterial activity and toxicity mechanism. Nano-Micro Lett. 2015;7(3):219-42.

25. Raghupathi KR, Koodali RT, Manna AC. Size-dependent bacterial growth inhibition and mechanism of antibacterial activity of zinc oxide nanoparticles. Langmuir. 2011;27(7):4020-8.

26. Gupta A, Srivastava R. Zinc oxide nanoleaves: a scalable disperser-assisted sonochemical approach for synthesis and an antibacterial application. Ultrason Sonochem. 2018;41:47-58.

27. Yu HY, Chen GY, Wang YB, Yao JM. A facile one-pot route for preparing cellulose nanocrystal/zinc oxide nanohybrids with high antibacterial and photocatalytic activity. Cellulose. 2015;22(1):261-73.

28. Mishra PK, Mishra H, Ekielski A, Talegaonkar S, Vaidya B. Zinc oxide nanoparticles: a promising nanomaterial for biomedical applications. Drug Discov Today. 2017;22(12):1825-34.

29. Dastjerdie EV, Oskoui M, Sayanjali E, Tabatabaei FS. In-vitro comparison of the antimicrobial properties of glass ionomer cements with zinc phosphate cements. Iran J Pharm Res. 2012;11(1):77-82.

30. Chou AHK, LeGeros RZ, Chen Z, Li YH. Antibacterial effect of zinc phosphate mineralized guided bone regeneration membranes. Implant Dent. 2007; 16(1):89-100.

31. Roguska A, Belcarz A, Pisarek M, Ginalska G, Lewandowska M. TiO 2 nanotube composite layers as delivery system for $\mathrm{ZnO}$ and $\mathrm{Ag}$ nanoparticles - An unexpected overdose effect decreasing their antibacterial efficacy. Mater Sci Eng C-Mater Biol Appl. 2015;51:158-66.

32. Gielda LM, DiRita VJ. Zinc Competition among the Intestinal Microbiota. mBio. 2012;3(4):00171-12.

33. Lopez CA, Skaar EP. The impact of dietary transition metals on host-bacterial interactions. Cell Host Microbe. 2018;23(6):737-48.

34. Vijayalakshmi K, Sivaraj D. Enhanced antibacterial activity of $\mathrm{Cr}$ doped ZnO nanorods synthesized using microwave processing. RSC Adv. 2015;5(84): 68461-9.

35. Winterhalter M, Ceccarelli M. Physical methods to quantify small antibiotic molecules uptake into Gram-negative bacteria. Eur J Pharm Biopharm. 2015; 95:63-7.

36. Shore AC, Coleman DC. Staphylococcal cassette chromosome mec: recent advances and new insights. Int J Med Microbiol. 2013;303(6-7):350-9.

37. Stefani S, Chung DR, Lindsay JA, Friedrich AW, Kearns AM, Westh $\mathrm{H}$, et al. Meticillin-resistant Staphylococcus aureus (MRSA): global epidemiology and harmonisation of typing methods. Int J Antimicrob Agents. 2012; 39(4):273-82.

38. Cavaco LM, Hasman H, Aarestrup FM. Zinc resistance of Staphylococcus aureus of animal origin is strongly associated with methicillin resistance. Vet Microbiol. 2011;150(3-4):344-8.

39. Hau SJ, Frana T, Sun J, Davies PR, Nicholson TL. Zinc resistance within swine-associated methicillin-resistant Staphylococcus aureus isolates in the United States is associated with multilocus sequence type lineage. Appl Environ Microbiol. 2017;83(15):9.

40. Argudin MA, Lauzat B, Kraushaar B, Alba P, Agerso Y, Cavaco L, et al. Heavy metal and disinfectant resistance genes among livestock-associated methicillin-resistant Staphylococcus aureus isolates. Vet Microbiol. 2016;191: 88-95.

41. Olechnowicz J, Tinkov A, Skalny A, Suliburska J. Zinc status is associated with inflammation, oxidative stress, lipid, and glucose metabolism. J Physiol Sci. 2018;68(1):19-31.

42. Bondzio A, Pieper R, Gabler C, Weise C, Schulze P, Zentek J, et al. Feeding low or pharmacological concentrations of zinc oxide changes the hepatic proteome profiles in weaned piglets. PLoS One. 2013;8(11):11.

43. Baek M, Chung HE, Yu J, Lee JA, Kim TH, Oh JM, et al. Pharmacokinetics, tissue distribution, and excretion of zinc oxide nanoparticles. Int J Nanomedicine. 2012;7:3081-97.

44. Paek HJ, Lee YJ, Chung HE, Yoo NH, Lee JA, Kim MK, et al. Modulation of the pharmacokinetics of zinc oxide nanoparticles and their fates in vivo. Nanoscale. 2013;5(23):11416-27.

45. Cho WS, Kang BC, Lee JK, Jeong J, Che JH, Seok SH. Comparative absorption, distribution, and excretion of titanium dioxide and zinc oxide nanoparticles after repeated oral administration. Part Fibre Toxicol. 2013;10:9.

46. Wang C, Lu JJ, Zhou L, Li J, Xu JM, Li WJ, et al. Effects of long-term exposure to zinc oxide nanoparticles on development, zinc metabolism and biodistribution of minerals ( $\mathrm{Zn}, \mathrm{Fe}, \mathrm{Cu}, \mathrm{Mn}$ ) in mice. PLoS One. 2016;11(10):14.

47. Jemai H, Messaoudi I, Chaouch A, Kerkeni A. Protective effect of zinc supplementation on blood antioxidant defense system in rats exposed to cadmium. J Trace Elem in Med Bio. 2007;21(4):269-73.

48. Gu YH, Zhao Z. Significance of the changes occurring in the levels of interleukins, SOD and MDA in rat pulmonary tissue following exposure to different altitudes and exposure times. Exp Ther Med. 2015;10(3):915-20.

49. Liu JH, Ma X, Xu YY, Tang H, Yang ST, Yang YF, et al. Low toxicity and accumulation of zinc oxide nanoparticles in mice after 270-day consecutive dietary supplementation. Toxicol Res. 2017;6(2):134-43.

50. Pati R, Das I, Mehta RK, Sahu R, Sonawane A. Zinc-oxide nanoparticles exhibit genotoxic, clastogenic, cytotoxic and actin depolymerization effects by inducing oxidative stress responses in macrophages and adult mice. Toxicol Sci. 2016;150(2):454-72.

51. Syama S, Sreekanth PJ, Varma HK, Mohanan PV. Zinc oxide nanoparticles induced oxidative stress in mouse bone marrow mesenchymal stem cells. Toxicol Mech Methods. 2014;24(9):644-53.

52. Arakha M, Roy J, Nayak PS, Mallick B, Jha S. Zinc oxide nanoparticle energy band gap reduction triggers the oxidative stress resulting into autophagymediated apoptotic cell death. Free Radic Biol Med. 2017;110:42-53.

53. Hou J, Wu YZ, Li X, Wei BB, Li SG, Wang XK. Toxic effects of different types of zinc oxide nanoparticles on algae, plants, invertebrates, vertebrates and microorganisms. Chemosphere. 2018;193:852-60.

54. Shin YJ, Lee WM, Kwak Jl, An YJ. Dissolution of zinc oxide nanoparticles in exposure media of algae, daphnia, and fish embryos for nanotoxicological testing. Chem Ecol. 2018;34(3):229-40.

55. Brun NR, Lenz M, Wehrli B, Fent K. Comparative effects of zinc oxide nanoparticles and dissolved zinc on zebrafish embryos and eleutheroembryos: importance of zinc ions. Sci Total Environ. 2014;476:657-66.

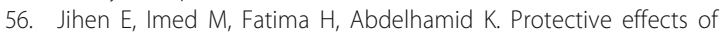
selenium (Se) and zinc ( $\mathrm{Zn}$ ) on cadmium (Cd) toxicity in the liver and kidney of the rat: histology and cd accumulation. Food Chem Toxicol. 2008;46(11):3522-7.

57. Chatzicharalampous C, Jeelani R, Mikhael S, Aldhaheri S, Najeemudin S, Morris RT, et al. Zinc: An essential metal for maintenance of female fertility. Fertil Steril. 2018;109(3):E19.

58. Kumar N, Krishnani KK, Kumar P, Singh NP. Zinc nanoparticles potentiates thermal tolerance and cellular stress protection of Pangasius hypophthalmus reared under multiple stressors. J Therm Biol. 2017;70:61-8. 
59. Torabi F, Shafaroudi MM, Rezaei N. Combined protective effect of zinc oxide nanoparticles and melatonin on cyclophosphamide-induced toxicity in testicular histology and sperm parameters in adult Wistar rats. Int J Reprod Biomed. 2017:15(7):403-12.

60. Lee CM, Jeong HJ, Yun KN, Kim DW, Sohn MH, Lee JK, et al. Optical imaging to trace near infrared fluorescent zinc oxide nanoparticles following oral exposure. Int J Nanomedicine. 2012;7:3203-9.

61. Pietroiusti A, Magrini A, Campagnolo L. New frontiers in nanotoxicology: gut microbiota/microbiome-mediated effects of engineered nanomaterials. Toxicol Appl Pharmacol. 2016;299:90-5.

62. Westmeier D, Hahlbrock A, Reinhardt C, Frohlich-Nowoisky J, Wessler S, Vallet $C$, et al. Nanomaterial-microbe cross-talk: physicochemical principles and (patho) biological consequences. Chem Soc Rev. 2018;47(14):5312-37.

63. Mercier-Bonin M, Despax B, Raynaud P, Houdeau E, Thomas M. Mucus and microbiota as emerging players in gut nanotoxicology: the example of dietary silver and titanium dioxide nanoparticles. Crit Rev Food Sci Nutr. 2018;58(6):1023-32.

64. Qiu KY, Durham PG, Anselmo AC. Inorganic nanoparticles and the microbiome. Nano Res. 2018;11(10):4936-54.

65. Yausheva E, Miroshnikov S, Sizova E. Intestinal microbiome of broiler chickens after use of nanoparticles and metal salts. Environ Sci Pollut Res. 2018:25(18):18109-20.

66. Feng YN, Min LJ, Zhang WD, Liu J, Hou ZM, Chu MQ, et al. Zinc oxide nanoparticles influence microflora in ileal digesta and correlate well with blood metabolites. Front Microbiol. 2017:8:10.

67. Li JQ, Chen HQ, Wang B, Cai CX, Yang X, Chai ZF, et al. ZnO nanoparticles act as supportive therapy in DSS-induced ulcerative colitis in mice by maintaining gut homeostasis and activating Nrf2 signaling. Sci Rep. 2017;7:11.

Ready to submit your research? Choose BMC and benefit from:

- fast, convenient online submission

- thorough peer review by experienced researchers in your field

- rapid publication on acceptance

- support for research data, including large and complex data types

- gold Open Access which fosters wider collaboration and increased citations

- maximum visibility for your research: over $100 \mathrm{M}$ website views per year

At $\mathrm{BMC}$, research is always in progress.

Learn more biomedcentral.com/submissions 